\title{
Broken Component
}

National Cancer Institute

\section{Source}

National Cancer Institute. Broken Component. NCI Thesaurus. Code C118638.

A part of a device has been fractured or damaged. 